\title{
A Late Caddo Cemetery at the A. Davis Site in the Little Cypress Creek Basin, Upshur County, Texas
}

Timothy K. Perttula

Heritage Research Center, Stephen F. Austin State University

Bo Nelson

Heritage Research Center, Stephen F. Austin State University

Follow this and additional works at: https://scholarworks.sfasu.edu/ita

Part of the American Material Culture Commons, Archaeological Anthropology Commons, Environmental Studies Commons, Other American Studies Commons, Other Arts and Humanities Commons, Other History of Art, Architecture, and Archaeology Commons, and the United States History Commons

Tell us how this article helped you.

This Article is brought to you for free and open access by the Center for Regional Heritage Research at SFA ScholarWorks. It has been accepted for inclusion in Index of Texas Archaeology: Open Access Gray Literature from the Lone Star State by an authorized editor of SFA ScholarWorks. For more information, please contact cdsscholarworks@sfasu.edu. 


\section{A Late Caddo Cemetery at the A. Davis Site in the Little Cypress Creek Basin, Upshur County, Texas}

\section{Creative Commons License}

\section{(c) (1) \&}

This work is licensed under a Creative Commons Attribution-NonCommercial 4.0 International License 


\title{
A Late Caddo Cemetery at the A. Davis Site in the Little Cypress Creek Basin, Upshur County, Texas
}

\author{
Timothy K. Perttula and Bo Nelson
}

\begin{abstract}
INTRODUCTION
The A. Davis site is a previously unreported Late Caddo period Titus phase cemetery in the Pineywoods of the Little Cypress Creek basin in Upshur County, Texas (Figure 1). There are notes and collections from the site in the Buddy Jones collection at the Gregg County Historical Museum, and our analysis of those materials are presented in this article.
\end{abstract}

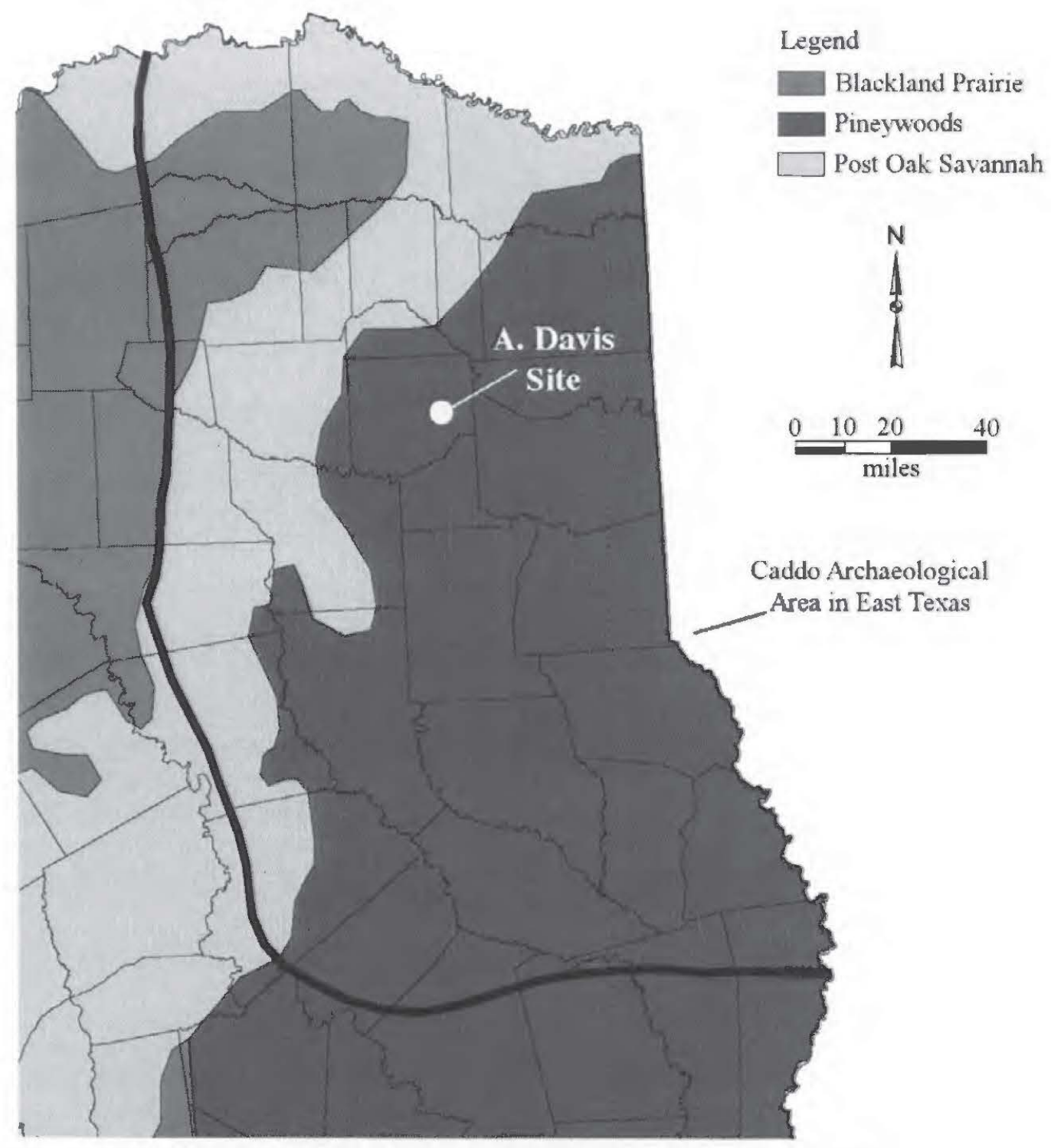

Figure 1. General location of the A. Davis site in Upshur County in East Texas. 


\section{AVAILABLE SITE INFORMATION}

The A. Davis site is on a natural rise between two small creeks on property owned in 1961 by A. Davis. The site is just east of the Frank Smith property line (Figure 2). The Titus phase Frank Smith cemetery (41UR326) is on the Frank Smith property (Perttula et al. 2012b).

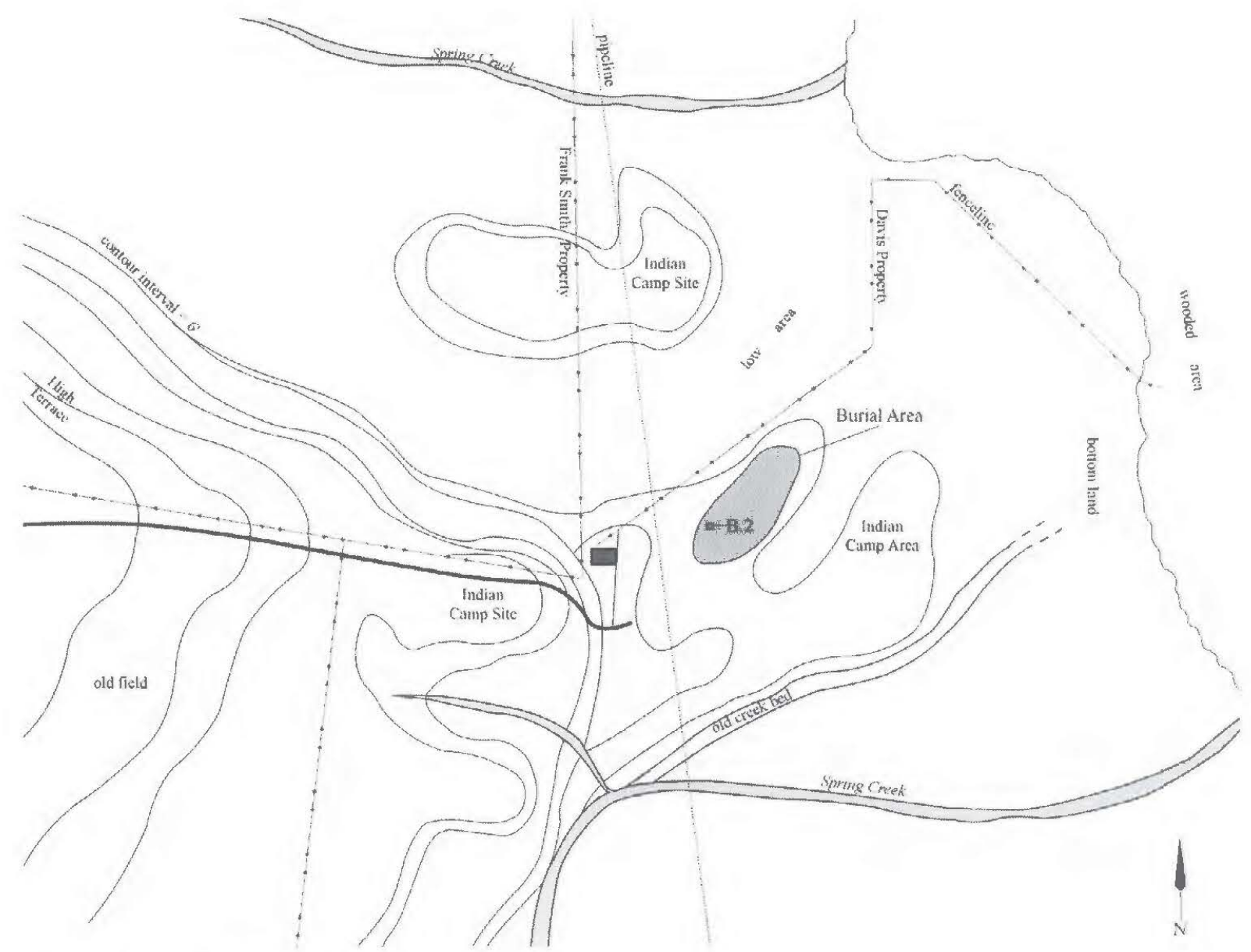

Figure 2. Buddy Jones map of the A. Davis site.

Buddy Jones investigated the A. Davis site in February 1961. He excavated at least one Caddo burial (Burial 2) that had whole ceramic vessels as funerary objects, and apparently also excavated Burial 1, based on the fact that there are artifacts from the Burial 1 fill in the collection. A map Jones drew at the time indicates that 11 burials were known at the site, and presumably the other nine burials had been excavated by other unknown individuals, but their locations were still known and apparent (Figure 3). These burials were well-spaced across the natural rise.

\section{VESSEL RECORDATION FORMS FROM BURIAL 2}

There are seven whole or mostly whole vessels in Burial 2 at the A. Davis site. These include two utility ware jars (with brushed-incised punctated and incised decorations, respectively), a Ripley Engraved, var. Galt bowl, three Ripley Engraved, var. McKinney carinated bowls, and one Ripley Engraved, var. Pilgrims carinated bowl. 


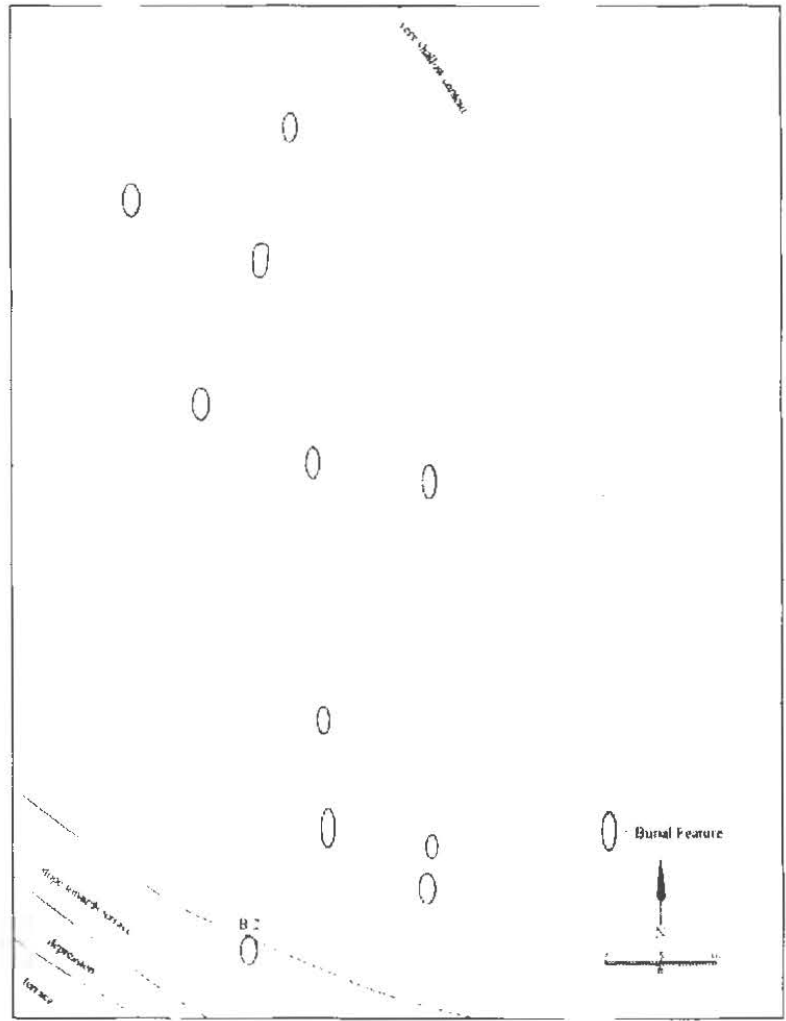

Figure 3. Map of the burials at the A. Davis site.
SITE NAME OR SITE NUMBER: A. Davis Burial site

VESSEL NO.: 2003.08.1207

NON-PLASTICS AND PASTE: grog

VESSEL FORM: Jar

RIM AND LIP FORM: Everted rim and a rounded lip

CORE COLOR: $F$ (fired in a reducing environment and cooled in the open air)

INTERIOR SURFACE COLOR: reddish-brown; int. red wash; fire clouding on the body and base

EXTERIOR SURFACE COLOR: reddish-brown; fire clouds on the rim, hody, and base

WALL THICKNESS (RIM, BODY, AND BASE IN MM): rim, $3.6 \mathrm{~mm}$; body, $5.1 \mathrm{~mm}$; base, $7.9 \mathrm{~mm}$

INTERIOR SURFACE TREATMENT: smoothed EXTERIOR SURFACE TREATMENT: none

HEIGHT (IN CM): 12.6

ORIFICE DIAMETER (IN CM): 15.2

DIAMETER AT BOTTOM OF RIM OR NECK (IN CM): 15.0

BASE DIAMETER (IN CM) AND SHAPE OF BASE: 6.4; flat and circular

ESTIMATED VOLUME (IN LITERS): 1.15

DECORATION (INCLUDING MOTIF AND ELEMENTS WHEN APPARENT): The rim has two rows of tool punctations, one under the lip and the other at the rim-body juncture. The area between the punctated rows has horizontal brushing marks as well as incised triangles drawn over the brushing. The vessel body has both diagonal and vertical brushing marks that extend to within $2.0 \mathrm{~cm}$ of the base (Figure 4).

PIGMENT USE AND LOCATION ON VESSEL: none

TYPE AND VARIETY [IF KNOWN]: Unidentified utility ware

SITE NAME OR SITE NUMBER: A. Davis Burial site

VESSEL NO.: 2003.08.1208

NON-PLASTICS AND PASTE: grog 

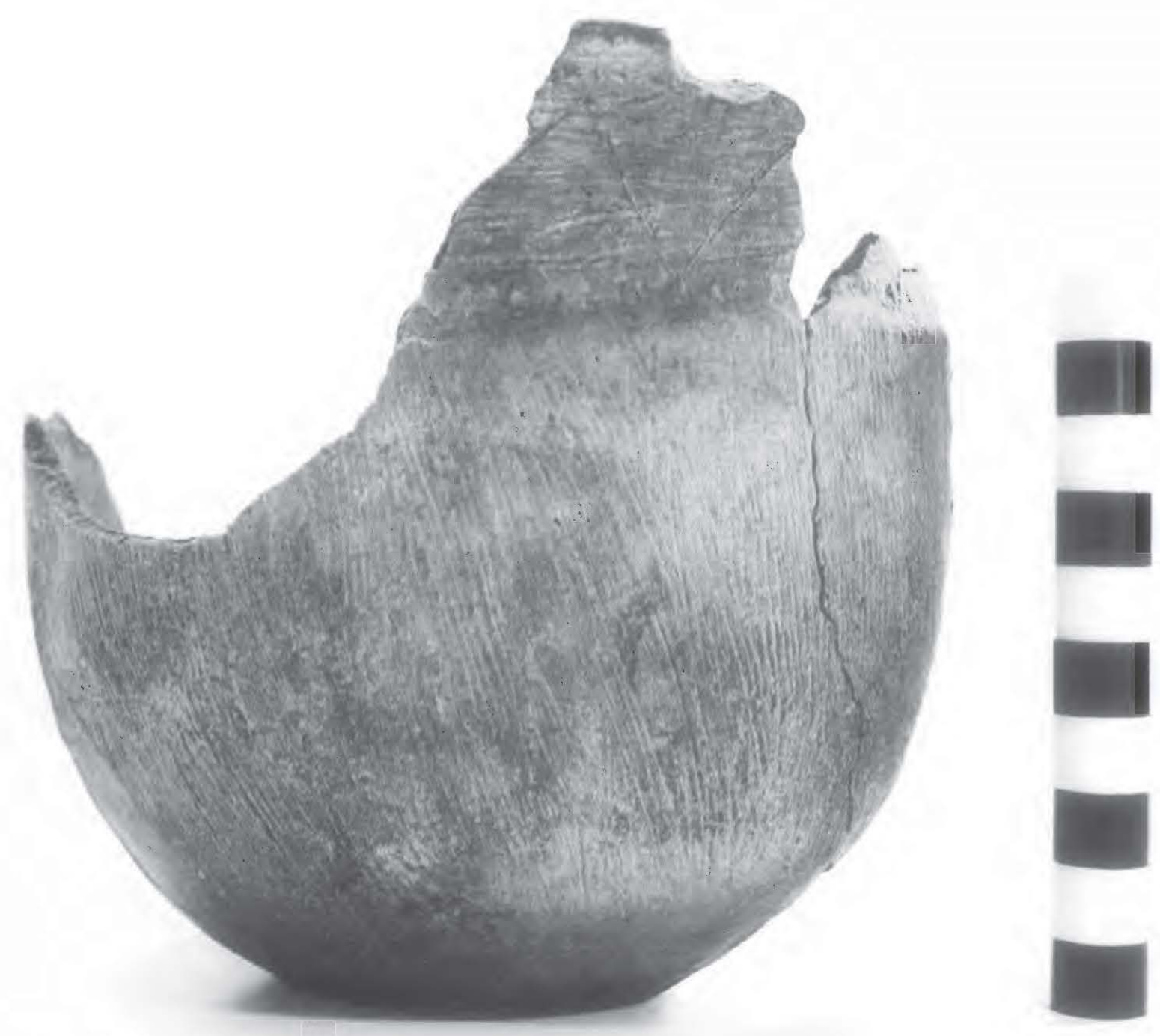

Figure 4. Brushed-punctated jar, Burial 2, A. Davis site.

VESSEL FORM: Bowl

RIM AND LIP FORM: direct rim and a rounded lip

CORE COLOR: F (fired in a reducing environment and cooled in the open air)

INTERIOR SURFACE COLOR: red

EXTERIOR SURFACE COLOR: red

WALL THICKNESS (RIM, BODY, AND BASE IN MM): rim, $4.0 \mathrm{~mm}$

INTERIOR SURFACE TREATMENT: burnished

EXTERIOR SURFACE TREATMENT: burnished 
HEIGHT (IN CM): 7.0

ORIFICE DIAMETER (IN CM): 14.7

DIAMETER AT BOTTOM OF RIM OR NECK (IN CM): N/A

BASE DIAMETER (IN CM) AND SHAPE OF BASE: 4.4; flat and circular

ESTIMATED VOLUME (IN LITERS): 0.40

DECORATION (INCLUDING MOTIF AND ELEMENTS WHEN APPARENT): The vessel has a red slip on both interior and exterior vessel surfaces. The rim panel has an engraved scroll and circle motif repeated four times around the vessel. The central circle elements have an internal central diamond element. The scroll fill zones include vertical excised lines as well as excised triangles and brackets (Figure 5). There is also a single horizontal engraved line on the interior vessel surface at the carination.

PIGMENT USE AND LOCATION ON VESSEL: none

TYPE AND VARIETY [IF KNOWN]: Ripley Engraved, var. Galt
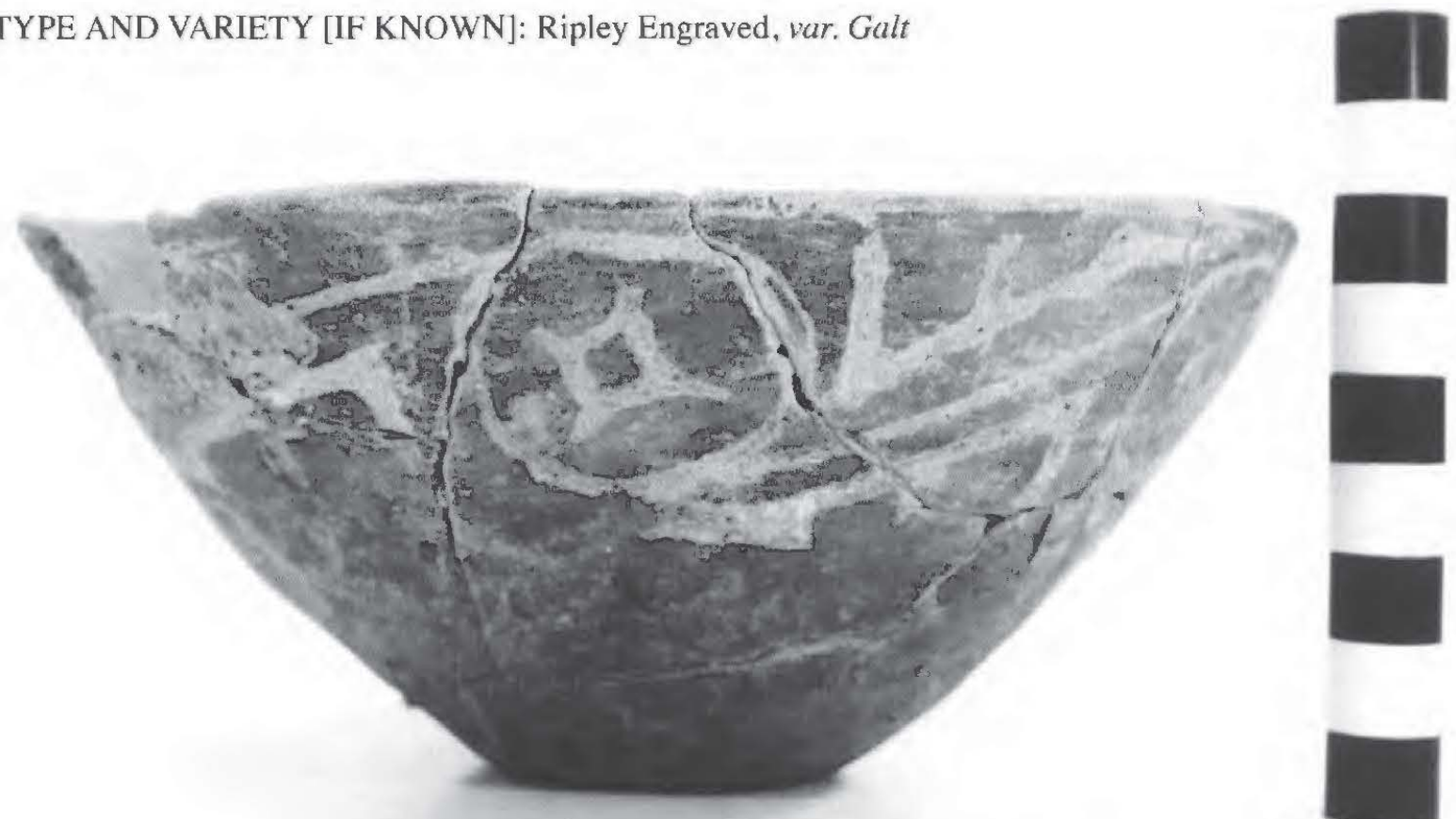

Figure 5. Ripley Engraved, var. Galt bowl, Burial 2, A. Davis site.

SITE NAME OR SITE NUMBER: A. Davis Burial site

VESSEL NO.: 2003.08.1212

NON-PLASTICS AND PASTE: grog

VESSEL FORM: Carinated bowl 
RIM AND LIP FORM: Direct rim and a rounded, exterior folded lip

CORE COLOR: F (fired in a reducing environment and cooled in the open air)

INTERIOR SURFACE COLOR: dark yellowish-brown; fire clouds on the rim, body, and base

EXTERIOR SURFACE COLOR: dark yellowish-brown; fire clouds on the rim, body, and base

WALL THICKNESS (RIM, BODY, AND BASE IN MM): rim, $6.0 \mathrm{~mm}$

INTERIOR SURFACE TREATMENT: burnished

EXTERIOR SURFACE TREATMENT: burnished

HEIGHT (IN CM): 7.6

ORIFICE DIAMETER (IN CM): 18.4

DIAMETER AT BOTTOM OF RIM OR NECK (IN CM): 18.0

BASE DIAMETER (IN CM) AND SHAPE OF BASE: 6.2; flat and circular

\section{ESTIMATED VOLUME (IN LITERS): 0.84}

DECORATION (INCLUDING MOTIF AND ELEMENTS WHEN APPARENT): The central elements of the motif are engraved diamonds and circles, each repeated two times around the vessel. The circles have interior central dots, while the diamonds have a central interior diamond and negative oval (Figure 6). The diamonds are the central element in horizontal scrolls that end in excised brackets. There are alternating rows of excised pendant triangles and dashes under the vessel lip and at the carination. There is also a single horizontal engraved line on the interior vessel surface at the carination.

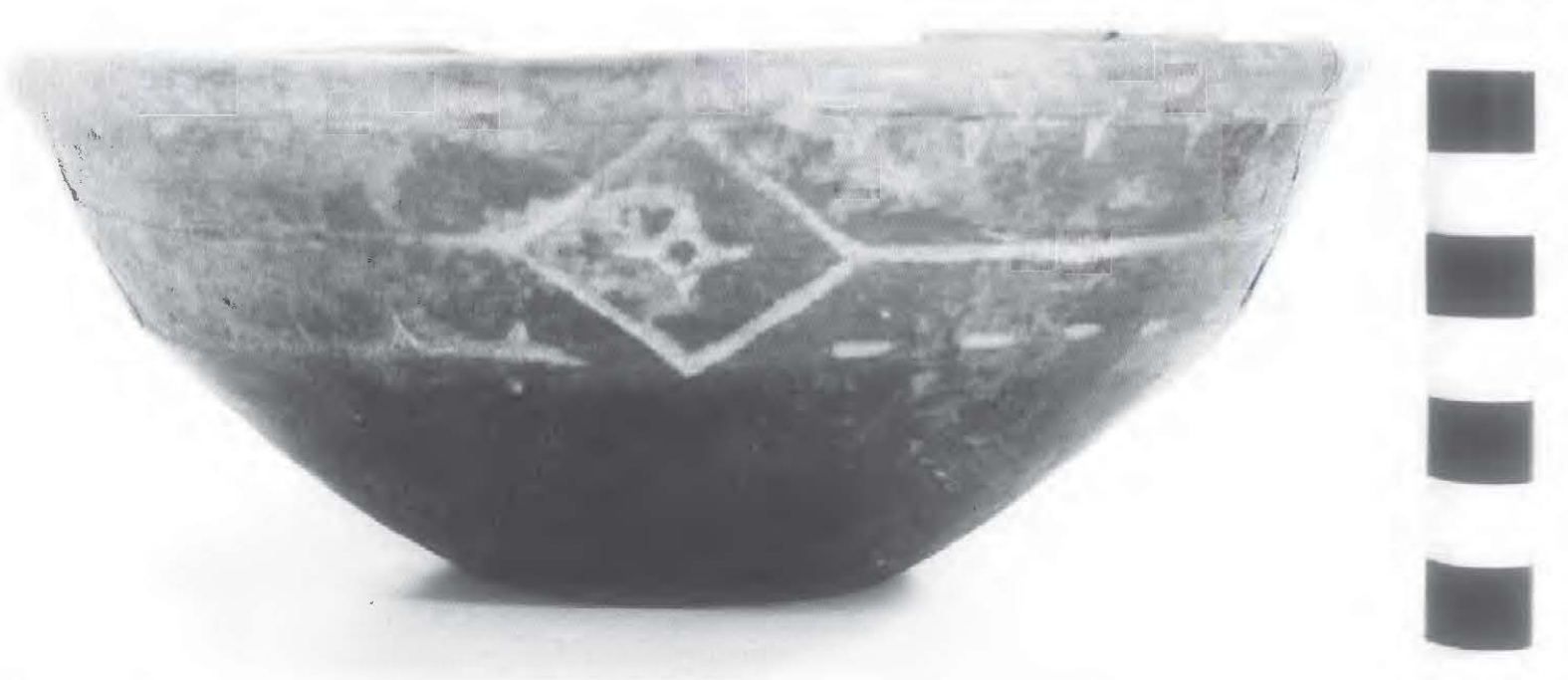

Figure 6. Ripley Engraved, var. McKinney carinated bowl, Burial 2, A. Davis site. 
PIGMENT USE AND LOCATION ON VESSEL: none

TYPE AND VARIETY [IF KNOWN]: Ripley Engraved, var. McKinney

SITE NAME OR SITE NUMBER: A. Davis Burial site

VESSEL NO.: 2003.08.1213

NON-PLASTICS AND PASTE: grog

VESSEL FORM: Carinated bowl

RIM AND LIP FORM: Direct rim and a rounded, exterior folded lip

CORE COLOR: $\mathrm{F}$ (fired in a reducing environment and cooled in the open air)

INTERIOR SURFACE COLOR: dark yellowish-brown

EXTERIOR SURFACE COLOR: dark yellowish-brown; lire clouds on the body

WALL THICKNESS (RIM, BODY, AND BASE IN MM): rim, $8.2 \mathrm{~mm}$

INTERIOR SURFACE TREATMENT: smoothed

EXTERIOR SURFACE TREATMENT: burnished

HEIGHT (IN CM): 10.8

ORIFICE DIAMETER (IN CM): 20.7

DIAMETER AT BOTTOM OF RIM OR NECK (IN CM): 20.5

BASE DIAMETER (IN CM) AND SHAPE OF BASE: 6.6; flat and circular

ESTIMATED VOLUME (IN LITERS): 1.3

DECORATION (INCLUDING MOTIF AND ELEMENTS WHEN APPARENT): The central elements of the motif are engraved diamonds repeated four times around the vessel. The diamonds have a central interior diamond (Figure 7). The diamonds are the central element in connected horizontal scrolls. There are rows of excised pendant triangles under the vessel lip and at the carination. There is also a single horizontal engraved line on the interior vessel surface at the carination.

PIGMENT USE AND LOCATION ON VESSEL: none

TYPE AND VARIETY [IF KNOWN]: Ripley Engraved, var. McKinney

\section{SITE NAME OR SITE NUMBER: A. Davis Burial site}

VESSEL NO.: 2003.08.1214 


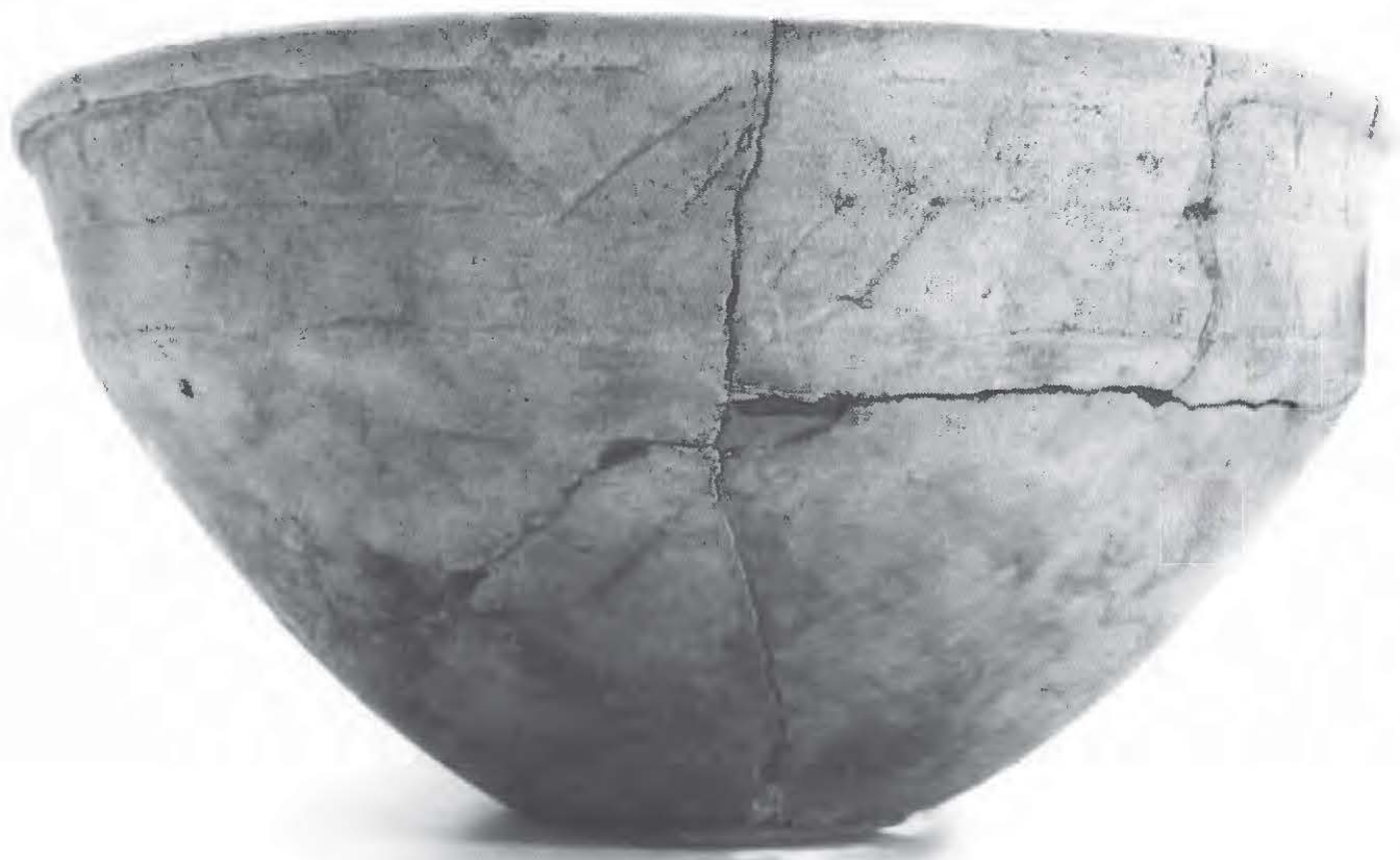

Figure 7. Ripley Engraved, var. McKinney carinated bowl, Burial 2, A. Davis site.

NON-PLASTICS AND PASTE: gray

VESSEL FORM: Carinated bowl

RIM AND LIP FORM: Direct rim and a rounded, exterior folded lip

CORE COLOR: $\mathrm{F}$ (fired in a reducing environment and cooled in the open air)

INTERIOR SURFACE COLOR: yellowish-brown

EXTERIOR SURFACE COLOR: dark yellowish-brown

WALL THICKNESS (RIM, BODY, AND BASE IN MM): rim, $6.6 \mathrm{~mm}$

INTERIOR SURFACE TREATMENT: smoothed

EXTERIOR SURFACE TREATMENT: burnished

HEIGHT (IN CM): 14.3

ORIFICE DIAMETER (IN CM): 29.0

DIAMETER AT BOTTOM OF RIM OR NECK (IN CM): 28.6

BASE DIAMETER (IN CM) AND SHAPE OF BASE: 9.6; flat and circular

ESTIMATED VOLUME (IN LITERS): 3.7 
DECORATION (INCLUDING MOTIF AND ELEMENTS WHEN APPARENT): The central elements of the motif are engraved diamonds and circles, each repeated two times around the vessel. The circles each have a single interior central diamond with a negative oval, while the diamonds have a central interior diamond and negative oval (Figure 8). The diamonds are the central element in horizontal scrolls that end in cross-hatched engraved brackets. There are rows of excised pendant triangles under the vessel lip and at the carination. There is also a single horizontal engraved line on the interior vessel surface at the carination.

PIGMENT USE AND LOCATION ON VESSEL: none

TYPE AND VARIETY [IF KNOWN]: Ripley Engraved, var. McKinney
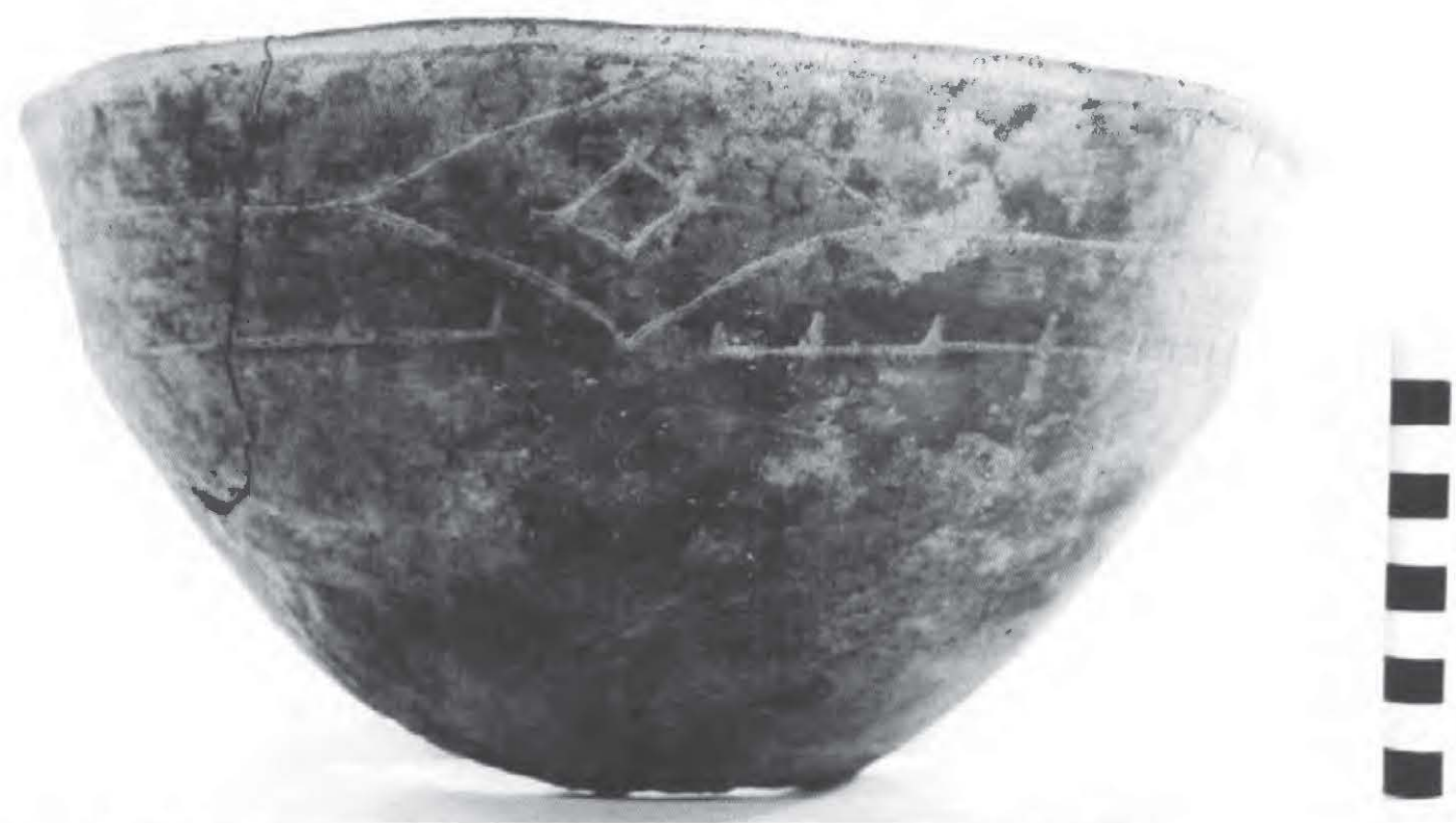

Figure 8. Ripley Engraved, var. McKinney carinated bowl, Burial 2, A. Davis site.

SITE NAME OR SITE NUMBER: A. Davis Burial site

VESSEL NO.: 2003.08.1380

NON-PLASTICS AND PASTE: grog

VESSEL FORM: Carinated bowl

RIM AND LIP FORM: Direct rim and a rounded, exterior folded lip

CORE COLOR: $F$ (fired in a reducing environment and cooled in the open air)

INTERIOR SURFACE COLOR: dark brown

EXTERIOR SURFACE COLOR: brown

WALL THICKNESS (RIM, BODY, AND BASE IN MM): rim, $6.2 \mathrm{~mm}$; body, $7.0 \mathrm{~mm}$ 
INTERIOR SURFACE TREATMENT: smoothed

EXTERIOR SURFACE TREATMENT: burnished

HEIGHT (IN CM): 6.8

ORIFICE DIAMETER (IN CM): 12.1

DIAMETER AT BOTTOM OF RIM OR NECK (IN CM): 12.2

BASE DIAMETER (IN CM) AND SHAPE OF BASE: 5.3; flat and circular

ESTIMATED VOLUME (IN LITERS): 0.49

DECORATION (INCLUDING MOTIF AND ELEMENTS WHEN APPARENT): The rim panel has an engraved interlocking horizontal scroll motif repeated four times around the vessel. The main part of the horizontal scroll is connected to the upper part of the rim and the vessel carination with hatched brackets. There are engraved hooked arms on either side of the interlocking horizontal scrolls. Each repeating motif is divided by a hatched bracket (Figure 9).

PIGMENT USE AND LOCATION ON VESSEL: white pigment

TYPE AND VARIETY [IF KNOWN]: Ripley Engraved, var. Pilgrims


Figure 9. Ripley Engraved, var. Pilgrims carinated bowl, Burial 2, A. Davis site. 


\section{SITE NAME OR SITE NUMBER: A. Davis Burial site}

VESSEL NO.: 2003.08.1381

NON-PLASTICS AND PASTE: grog

VESSEL FORM: Jar

RIM AND LIP FORM: Everted rim and rounded lip

CORE COLOR: $\mathrm{F}$ (fired in a reducing environment and cooled in the open air)

INTERIOR SURFACE COLOR: yellowish-brown

EXTERIOR SURFACE COLOR: yellowish-brown; fire clouds on the rim, body, and base

WALL THICKNESS (RIM, BODY, AND BASE IN MM): rim, $6.2 \mathrm{~mm}$; body, $7.9 \mathrm{~mm}$; base, $7.4 \mathrm{~mm}$

INTERIOR SURFACE TREATMENT: smoothed

EXTERIOR SURFACE TREATMENT: none

HEIGHT (IN CM): N/A

ORIFICE DIAMETER (IN CM): I8.0

DIAMETER AT BOTTOM OF RIM OR NECK (IN CM): 17.8

BASE DIAMETER (IN CM) AND SHAPE OF BASE: 8.4; llat and circular

ESTIMATED VOLUME (IN LITERS): N/A

DECORATION (INCLUDING MOTIF AND ELEMENTS WHEN APPARENT): There are vertical incised lines on the rim, and a single horizontal incised line at the rim-body juncture (Figure 10).

PIGMENT USE AND LOCATION ON VESSEL: none

TYPE AND VARIETY [IF KNOWN]: Unidentified utility ware

\section{ARTIFACTS FROM THE FILL OF BURIAL 1}

There apparently were no complete vessels in Burial 1, or none remained at the time Buddy Jones investigated the burial feature. Instead there were 36 plain and decorated sherds from the burial fill, along with a ferruginous sandstone grinding slab fragment. All but one of the sherds are from grog-tempered vessels; one plain body sherd is bone-tempered. There are 15 plain body sherds ( $93 \%$ grog-tempered) and four grog-tempered base sherds.

Four of the sherds are from fine wares, including a bottle with curvilinear engraved lines $(n=2)$ and two carinated bowl sherds. One of these is a rim (direct with a rounded, exterior folded lip) with a horizontal engraved line under the lip, and the other has parallel engraved lines. 


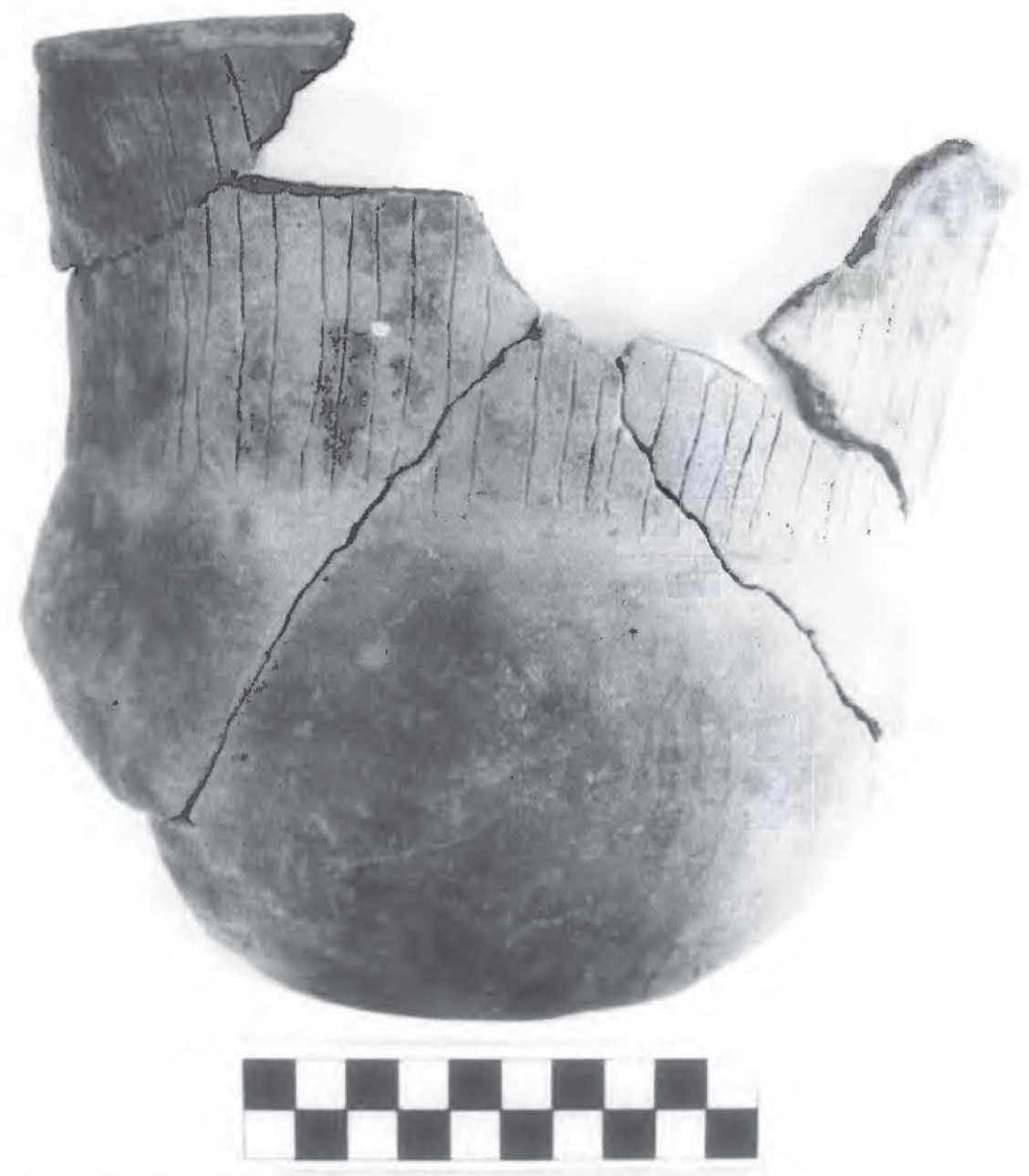

Figure 10. Incised jar, Burial 2, A. Davis site.

There are 13 decorated utility ware sherds in the Burial 1 fill, seemingly from more than one vessel. This includes an everted rim jar sherd with a tool punctated row under the lip, as well as brushed $(n=6)$, brushedpunctated $(n=1)$, incised $(n=2)$, and incised-punctated sherds $(n=3)$. One of the incised-punctated sherds is from a Maydelle Incised jar with a row of tool punctations above diagonal incised lines. The brushed sherds have parallel, opposed, and overlapping brushed marks, while the brushed-punctated sherd is from a Pease Brushed-Incised vessel that has parallel brushed marks with a row of tool punctations pushed through the brushing. The two incised body sherds have parallel lines. One of the incised-punctated sherds has parallel incised lines adjacent to a row of tool punctations, and the other has an incised zone filled with a row of tool punctations.

\section{MISCELLANEOUS ARTIFACTS FROM THE JONES EXCAVATION}

In addition to the whole vessels from Burial 2 and the artifacts from the fill of Burial 1 , there are also 52 sherds from miscellaneous contexts at the site (Table 1); 22 of the sherds are decorated. These likely are from the fill of Burial 2. The plain shell-tempered sherds mark a Late Caddo occupation, as shell-tempered vessels (traded from either McCurtain or Belcher phase Caddo groups living to the north on the Red River, or east on the Red River below the Great Bend, respectively) were not made in the Big Cypress Creek basin, and tend to appear only after ca. A.D. 1400 in this region (Perttula et al. 2012a). The remainder of the sherds are either grog-tempered $(79 \%)$ or bone-tempered $(17 \%)$. 
Table 1. Miscellaneous artifacts from the A. Davis site.

\begin{tabular}{llll}
\hline Ceramic ware & Grog-tempered & Bone-tempered & Shell-tempered \\
\hline Plain & 21 & 7 & 2 \\
Punctated & 6 & 2 & - \\
Brushed & 1 & - & - \\
Brushed-Punctated & 1 & - & - \\
Brushed-Punctated-Incised & 1 & - & - \\
Incised & 5 & - & - \\
Appliqued & 1 & - & 2 \\
Engraved & 5 & - & \\
\hline
\end{tabular}

There are 13 rims in the miscellaneous collection of sherds from at least 6-7 different vessels. These include four plain grog-tempered rims with direct rims and rounded-exterior folded and flat lips; these are likely from bowls and carinated bowls. There are also plain body sherds from shell-tempered $(n=2)$, grogtempered $(n=15)$, and bone-tempered $(n=7)$ vessels, as well as six grog-tempered base sherds.

The other nine rims are from decorated vessels: incised $(n=3)$, punctated $(n=2)$, brushed-punctated $(n=1)$, appliqued $(n=1)$, and engraved $(n=2)$. All but one of the punctated rims are from grog-tempered vessels; the other rim has bone temper. The incised rims have diagonal or horizontal elements (Figure $11 \mathrm{~b}$ ), with direct profiles and rounded to flat lips. The punctated rims have horizontal and diagonal rows of tool punctations. The one brushed-punctated rim is from a Pease Brushed-Incised jar with horizontal brushing on the rim itself, with a border of tool punctations under the lip and a second row at mid-rim; the punctations have been pushed through the brushing marks. The last utility ware rim has a diagonal appliqued element.

One fine ware rim has a horizontal engraved line under the lip, while the other has a horizontal engraved line and an excised bracket divider. This rim is from a Ripley Engraved, var. unspecified carinated bowl.

The decorated body sherds include sherds from utility wares $(n=10)$ and fine wares $(n=3)$. The utility wares include sherds with rows of tool punctations ( $n=4$ ) (see Figure Ilc), rows of fingernail punctations $(n=1)$, diagonal and horizontal incised lines $(n=1)$, parallel incised lines $(n=2)$, parallel brushed $(n=1)$, and an incised-brushed-punctated lower rim and body sherd. This particular sherd is from a Pease Brushed-Incised jar with horizontal incised lines on the rim, and vertical brushing marks on the vessel body. There is at least one vertical row of tool punctations pushed through the brushing.

Two of the engraved sherds are from bottles, including a grog-tempered Ripley Engraved bottle with widely-spaced curvilinear engraved lines and hatched pendant triangles (see Figure 1la). The other engraved body sherd has horizontal lines and portions of a circular element, possibly a Ripley Engraved carinated bowl motif.

In addition to the ceramic sherds, a fragment of a Middle-to-Late Archaic hematite grooved axe (see Turner 2006) was in the collection (GCHM accession no. 2003.08.1210). 

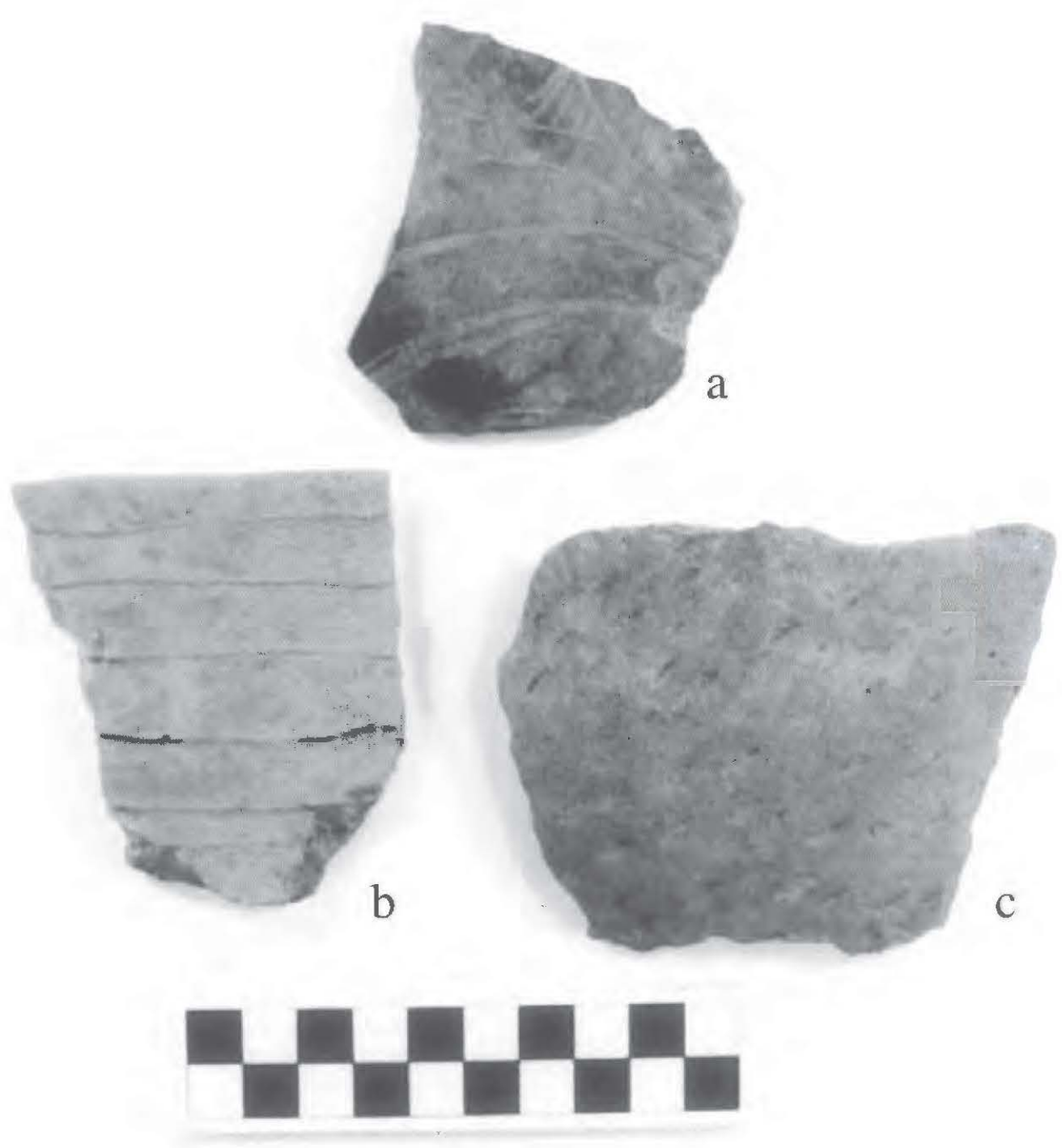

Figure 11. Decorated sherds from miscellaneous contexts: a, Ripley Engraved bottle body; b, horizontal incised rim; c, tool punctated body.

\section{SUMMARY AND CONCLUSIONS}

The whole vessels and miscellaneous sherds from burial contexts at the A. Davis site indicate that the primary component here is a Late Caddo Titus phase cemetery, likely a family cemetery used by neighboring farmstead families in the Little Cypress Creek basin. The grooved axe fragments points to a limited use of the landform during some part of the lengthy Archaic period. The predominance of Ripley Engraved, var. McKinney fine ware vessels in Burial 2 suggests that this burial, at least, dates to the latter part of the Titus phase (after ca. A.D. 1550), as do most of the other ancestral Caddo burials in cemeteries in this part of the Little Cypress Creek basin (see Perttula et al. 2012b).

\section{ACKNOWLEDGMENTS}

We thank Patti Haskins of the Gregg County Historical Museum for the opportunity to study the vessels and collections from the A. Davis site. Lance Trask prepared several of the figures used in this article. 


\section{REFERENCES CITED}

Perttula, T. K., M. B. Trubitt, and J. S. Girard

2012a The Use of Shell-Tempered Pottery in the Caddo Area of the Southeastern United States. Southeastern Archaeology 30(2):242-267.

Perttula, T. K., M. Walters, and B. Nelson

2012b Little Cypress Creek Basin Archaeology: Six Late Caddo Period Cemeteries in Upshur County, Texas. Special Publication No. 22. Friends of Northeast Texas Archaeology, Austin and Pittsburg.

Turner, R. L.

2006 Hematite Axes of Northeast Texas. Bulletin of the Texas Archeological Society 77:1-32. 